\title{
Thermal and Physicochemical Characterization of Fibers from Coffee Hulls as Filler for Linear Low Density Polyethylene (LLDPE)
}

\author{
Ahmat Tom1, Abel Tame², Paul Nestor Djomou Djonga ${ }^{3 *}$, Bakary Tigana Djonse Justin ${ }^{3,4}$, \\ Eugenie Géraldine Nga Abena ${ }^{5}$
}

\begin{abstract}
${ }^{1}$ Department of Energy Engineering, University Institute of Technology, University of Ngaoundere, Ngaoundere, Cameroon ${ }^{2}$ Department of Chemistry, Faculty of Science, University of Yaoundé I, Yaoundé, Cameroon

${ }^{3}$ Department of Textile and Leather Engineering, National Advanced School of Engineering of Maroua, Maroua, Cameroon

${ }^{4}$ Department of Chemistry, Faculty of Science, University of Maroua, Maroua, Cameroon

${ }^{5}$ Department of Physics, Faculty of Science, University of Yaoundé I, Yaoundé, Cameroon

Email: ^djomoupaul@gmail.com
\end{abstract}

How to cite this paper: Tom, A., Tame, A., Djonga, P.N.D., Justin, B.T.D. and Abena, E.G.N. (2021) Thermal and Physicochemical Characterization of Fibers from Coffee Hulls as Filler for Linear Low Density Polyethylene (LLDPE). Advances in Materials Physics and Chemistry, 11, 155-166. https://doi.org/10.4236/ampc.2021.1110015

Received: June 16, 2021

Accepted: October 17, 2021

Published: October 20, 2021

Copyright $\odot 2021$ by author(s) and Scientific Research Publishing Inc. This work is licensed under the Creative Commons Attribution International License (CC BY 4.0).

http://creativecommons.org/licenses/by/4.0/ (c) (i) Open Access

\begin{abstract}
This work presents the thermal, physical and chemical characterization of Coffee canephora, from littoral region of Cameroon, for their use as reinforcement for polymeric materials. The infrared of coffee hulls shows the presence of a large peak intensity at $3299 \mathrm{~cm}^{-1}$ that can be attributed to $\mathrm{O}-\mathrm{H}$ stretching group of alcohol (cellulose content in coffee pulp). The intensity $2926 \mathrm{~cm}^{-1}$ can be attributed to C-H stretching group of alkanes or the vibration of methoxy group of lignin. Thermo gravimetric analysis shows that around $440^{\circ} \mathrm{C}$, the biomass has been completely consumed; the temperature profiles show a peak at $86^{\circ} \mathrm{C}$ that could correspond to the loss of water as evaporation at a percentage of $8 \%$; the peak at $321^{\circ} \mathrm{C}$ is accompanied by a water loss of $64.50 \%$; this temperature is assimilated to the degradation of hemicelluloses; the temperature range from $321^{\circ} \mathrm{C}$ to $401^{\circ} \mathrm{C}$ is accompanied by a loss of mass of $22.80 \%$, which would be due to the degradation of cellulose. SEM images of the surface of raw coffee hulls, coffee hulls treated with caustic soda respectively clearly reveal gaps between the fibers. The results showed that the incorporation of coffee hulls fiber in LLDPE matrix might result in composites with suitable property application for various industrial fields; especially those that were mechanical features are crucial, such as the replacement of engineering plastics.
\end{abstract}

\section{Keywords}

Characterization, Coffee Hulls, Filler, LLDPE, Physicochemical and Thermal 


\section{Introduction}

A strong increase in environmental concerns has arisen in the last years. This fact, together with the continuous increase in petroleum prices and the overall depletion of fossil fuels, has encouraged researchers to develop new environmentally friendly materials [1] [2]. One of the engineering fields that have experienced a more valuable growth is that related to composite materials with natural fillers/reinforcements such as natural fiber reinforced plastics [2] [3]. The use of natural fillers/reinforcements into polymeric matrices could lead to multiple advantages, such as clear cost reduction, lightness and good balance on mechanical properties, and a marked low environmental impact as well, due to their abundance, availability, low density and high specific strength compared to synthetic fibers [4]. For these reasons, some technological sectors such as aerospace, automotive, building among others and other sectors, such as packaging, have shown a clear interest on these materials [2] [5] [6] [7]. This study focuses on the characterization of fibers from coffee shell (FCS) which was extracted from waste coffee hulls using alkaline treatment method. Waste coffee hulls are abundantly available at the end of each coffee season. It's either burned as waste or used as fertilizer due to its excellent biodegradable properties [8] [9] [10] [11]. This material, considered as waste, can be used as reinforcement of thermoplastic like linear low density polyethylene. The objective of this work is to develop new coffee hull fibers-based polyethylene composites with mechanical properties similar to the virgin LLDPE. The composites were characterized by mechanical properties.

Linear Low Density Polyethylene (LLDPE) is a type of plastic widely used in industrial products and household goods and especially as a matrix material in composites, due to low production cost, design flexibility, and recyclability, compared with other polymers. Other potential properties of LLDPE include heat distortion temperature, flame retardant, transparency, and dimensional stability. Besides, LLDPE also suits filling, reinforcing and blending [12]. This research is aimed at valorizing these waste coffee hulls, by using it to reinforce LLDPE, thereby giving it an added value and increasing farmer's incomes. Farmers will no more grow coffee only for their seed but also for their hulls.

\section{Materials and Methods}

\subsection{Materials}

In this study, we used the shells pulp from coffee Canephora and as matrix, granulate of Linear Low Density Polyethylene LLDPE granules obtained from the Department of chemical engineering at the Faculty of Science in Laval University of Quebec

\subsubsection{Raw Coffee Hulls}

Robusta coffee tree is a shrub of the Rubiaceae family. After its seed has been removed, coffee shell pulp is obtained. There are two varieties of coffee, the hulls used in this study is that of coffee Canephora (Robusta coffee). 
Coffee hulls were collected from a coffee factory in a rural area of Cameroon (Nkongsamba) (Figure 1).

\subsubsection{Linear Low Density Polyethylene}

Linear-low-density PE LL1201 XV used is a blown film type polyethylene from Exxon Mobile Chemicals; It was used because it does not contain slip enhancing additives, with the following properties: melting temperature of $122^{\circ} \mathrm{C}$, density of $0.916 \mathrm{~g} \cdot \mathrm{cm}^{-3}\left(25^{\circ} \mathrm{C}\right)$ and melt-flow index (MFI) of $40 \mathrm{~g} /(10 \mathrm{~min})$ at $230^{\circ} \mathrm{C}$ (Figure 2).

\subsubsection{Preparation}

The preparation of the raw coffee hulls material for different analysis has been done, according to the following stages: (Figure 3 ).

\subsubsection{Physicochemical Characterization of Coffee Hulls} The following tests have been carried out:

1) Water and dry matter content

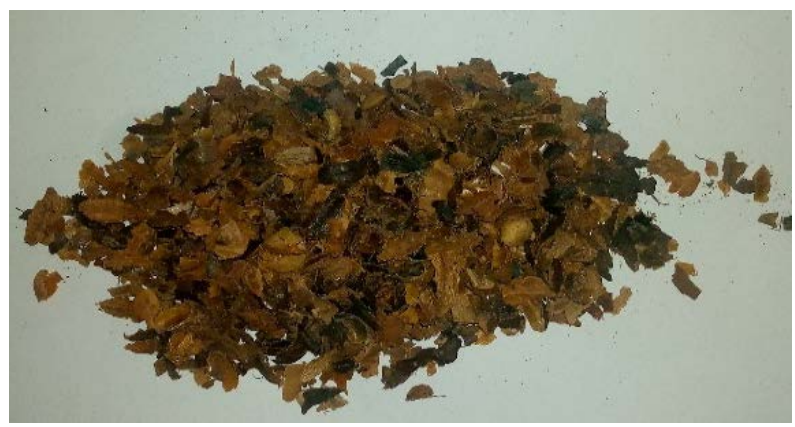

Figure 1. Coffee hulls at the moment of collection (May 2021).

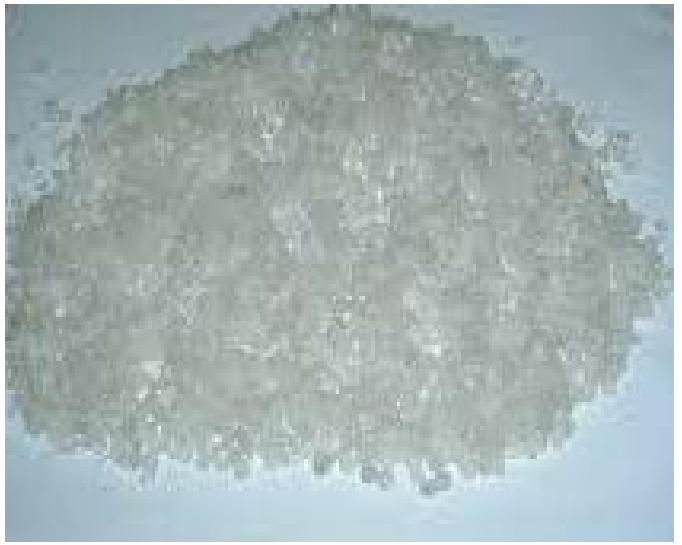

Figure 2. Linear low density polyethylene.

Drying $\Longrightarrow \begin{aligned} & \text { Mechanical grinding } \\ & \text { (on a Retsch } \\ & \text { brand mill) }\end{aligned} \Longrightarrow \begin{aligned} & \text { Sieving } \\ & \text { (granulate of } \\ & \Phi<0.75 \mathrm{~mm})\end{aligned} \Longrightarrow \begin{aligned} & \text { Physicochemical } \\ & \text { analysis }\end{aligned}$

Figure 3. Synoptic diagram of the process of transformation of raw coffee hulls into powder. 
The determination of the water content was carried out by AFNOR method (1982) reported by [13]. A mass of the fresh sample is dried at $105^{\circ} \mathrm{C}$ to constant weight in an oven for 24 hours.

\section{2) Crude fiber content}

The crude fiber content of the samples was determined by Weende method [14]. This method consists of treating the sample at the boiling point with sulfuric acid and then with soda. The residue obtained is dried and then calcined and weighed.

\section{3) Lignin content}

The lignin content was determined by the Klason method reported by [15]. This so-called Klason lignin method uses the property of the insolubility of lignin in a concentrated acidic medium which hydrolyzes and dissolves all other constituents. Its objective is to obtain an essentially woody residue.

\section{4) Cellulose content}

Cellulose is insoluble in ethanol as long as nitric acid converts lignin to alcohol soluble nitro products and hydrolyzes hemicelluloses.

\section{5) Apparent density}

The method described by Ernesto de la Torre Chauvin in 2015 [16] was used to evaluate the apparent density (Equation (1)). The measure of apparent density consists to place empty volumeter of capacity $1 \mathrm{~m}^{3}$ on the SEDITECH balance with a precision of 1/1000 and tare. Fill the volumeter with coffee hulls until 1 $\mathrm{m}^{3}$. For a volume $V_{i}$ of powder, record the mass $m_{i}$. Determine the value of mean and the standard deviation which represents the density $\rho$ of the micronized coffee hulls powder.

$$
\rho=\frac{m_{i}}{V_{i}}
$$

where $m_{i}=$ mass of the powder and $v_{i}=$ volume of the powder.

\section{6) Wetted density}

The method described by Ernesto de la Torre Chauvin in 2015 [16] was used to evaluate the wetted density. It consists to take an empty flask of volume $V_{o}$ and weight the mass of the flask $\left(m_{o}\right)$. Add a mass $\mathrm{m}_{1}$ of water, and a mass $\mathrm{m}_{2}$ of coffee hulls powder in the flask and let stand. Let all the mixture stand avoiding the formation of air bubbles in the flask and note the mass $\left(m_{3}\right)$. The wet density $\rho_{w}$ is given by Equation (2). Calculate the average and the standard deviation of the records.

$$
\rho_{w}=\frac{\rho_{\text {water }}\left(m_{2}-m_{o}\right)}{\left(m_{2}-m_{o}\right)-\left(m_{3}-m_{1}\right)}
$$

\section{7) Gravimetric Thermal Analysis (ATG)}

The thermal gravimetric analysis of coffee hulls was conducted by thermo gravimetric (TG-DTG) and differential scanning calorimetry (DSC). 20 to $22 \mathrm{mg}$ of very fine particles of coffee hulls sample was placed in an alumina crucible and taken for analysis. The samples were heated up, steadily at a rate of $10^{\circ} \mathrm{C} / \mathrm{min}$ from $24^{\circ} \mathrm{C}$ to $1000^{\circ} \mathrm{C}$ in the ambient air of the laboratory, and an isotherm at 
$900^{\circ} \mathrm{C}$ for 30 minutes under argon medium. A device of the brand LINSEIS STA-PT 1000 (from physic-chemistry of Mineral Materials Laboratory, Faculty of Science, University of Yaoundé 1, Cameroon) was used for the thermal analysis.

\section{8) Fourier transform infrared spectrum (FTIR)}

Coffee hulls were analyzed using the Perkin Elmer Frontier attenuated total reflectance (ATR) apparatus equipped with a Diamond/ZnSe crystal. $2 \mathrm{mg}$ of grounded powder was deposited on the crystal device. Each spectrum was obtained by 32 scans with a resolution of $4 \mathrm{~cm}^{-1}$ from 4000 to $600 \mathrm{~cm}^{-1}$.

\section{9) Scanning Electron Microscopy (SEM) Observation}

The morphology evaluation of coffee hulls surface was performed using a $\mathrm{Hi}$ tachi S-4800 scanning electron microscope (Hitachi, Japan). The samples were analyzed under nitrogen atmosphere, according to the following cycles: in the first cycle the sample was heated from $20^{\circ} \mathrm{C}$ to $200^{\circ} \mathrm{C}$, at a heating rate of $10^{\circ} \mathrm{C} \cdot \mathrm{min}^{-1}$.

\section{Composites Production}

In order to evaluate the importance of coffee hulls fiber composites, different coffee hulls fiber fractions were used in the composite besides the use of the compatibilization agent (MAPE). The impact of fiber proportion on absorption properties was assessed, it can caused changes in the mechanical properties of the composite. Coffee hulls fiber was blended with LLDPE and maleic anhydride polyethylene as coupling agent. The processing temperature in the extruder was $160^{\circ} \mathrm{C}$ in order to prevent coffee hulls fiber degradation and providing the fusion between the materials. The material was processed in twin screw extruder Werner \& Pfleiderer Krupp model ZSK-25, and chopped a SAGEC Model GS mill 70. The next step was to inject LLDPE and coffee hulls fiber as the specimen in injection Semerano Model 650/247 [17].

\subsection{Mechanical Test}

Tensile and flexural properties of the composites were measured by Emic (Model DL10000), testing machine, according to standards ASTM D 638 and ASTM D 790 respectively. The notched Izod impact strength was measured with an Olsen Tilsen Impact tester (model No. 43-02-01) according to ASTM D 256 using a pendulum of $5 \mathrm{ft}-\mathrm{lb}[17]$.

\subsection{Water Absorption Test}

The water absorption tests of pure LLDPE and for elaborated composites of polyethylene (LLDPE) and fiber from the coffee shell (FCS) at the proportions of $60 \%-40 \%$ and $80 \%-20 \%$ polymer - filler ratio were carried out following ASTM D 570-99 standard. Rectangular samples were cut with the dimension of $39 \times 10 \times 3 \mathrm{~mm}$, dried at $105^{\circ} \mathrm{C}$ until the weight remained unchanged, cooled to room temperature in a desiccator using silica gel, and immediately weighed with an accuracy of $0.001 \mathrm{~g}$. To investigate the water absorption of LLDPE/FCS com- 
posite, the sample was immersed in distilled water for $24 \mathrm{~h}$ at room temperature. Then, the sample were taken, with the excess water on their surface removed using a soft cloth, and weighed. The percentage of water absorption $(W)$ of the samples was calculated using the following:

$$
W(\mathrm{wt} \%)=\frac{W_{2}-W_{1}}{W_{1}} \times 100
$$

$W_{1}$ weight of the specimen before immersion,

$W_{2}$ weight of the specimen after immersion

\section{Results and Discussion}

\subsection{Chemical Composition of Coffee Hulls}

The results are given in Table 1 below.

The coffee hulls studied has a dry matter content of $88.1 \%$ and an organic matter content of $92.1 \%$. This high organic matter content shows that coffee hulls can be an important source of nutrients for microorganisms in anaerobic digestion, this can explain why it's used as fertilizer. These results are close to those of [18] On the other hand, these values are slightly higher than those of [19] which had $85.9 \%$ for dry matter and $87.7 \%$ for organic matter. In addition, [20] had high values, i.e. a dry matter content of $91.5 \%$ and $93.3 \%$ for organic matter. As regards the lignocellulosic composition, there are $40.1 \%$ crude fibers, $35.3 \%$ lignin and $41.4 \%$ cellulose. These results are in line with those of [18] who for these same compounds had $42.22 \%, 38 \%$ and $43.13 \%$ respectively. In addition, these contents are higher than that of [20] whose work revealed a crude fiber content of $36.6 \%$ against $21.4 \%$ of lignin. Such lignin (between $10 \%$ and $35 \%$ ) and cellulose (between $20 \%$ and $50 \%$ ) contents immediately make coffee shells a lignocellulosic biomass according to [21]. All these results demonstrate the variability in the composition of coffee shells. This can be explained by differences in the soil composition of the place of origin, the difference in the degree of maturity as well as the harvest period. But the fact remains that coffee hulls constitute a promising source of fibers that can be used as reinforcement or filler.

Table 1. Chemical composition of coffee hulls.

\begin{tabular}{cc} 
Constituents & Before pretreatment \\
\hline Dry matter content $\left(\mathrm{g} / 100^{*} \mathrm{~g}\right)$ & $88.1 \pm 0.1$ \\
Water content $\left(\mathrm{g} / 100^{*} \mathrm{~g}\right)$ & $11.9 \pm 0.1$ \\
organic matter content $\left(\mathrm{g} / 100^{+} \mathrm{g}\right)$ & $92.1 \pm 0.2$ \\
Ash content $\left(\mathrm{g} / 100^{+} \mathrm{g}\right)$ & $7.9 \pm 0.2$ \\
Reducing sugar content $\left(\mathrm{g} / 100^{*} \mathrm{~g}\right)$ & $0.020 \pm 0.003$ \\
Crude fiber content $\left(\mathrm{g} / 100^{+} \mathrm{g}\right)$ & $40.1 \pm 1.2$ \\
Lignin content $\left(\mathrm{g} / 100^{+} \mathrm{g}\right)$ & $35.3 \pm 1.8$ \\
Cellulose content $\left(\mathrm{g} / 100^{+} \mathrm{g}\right)$ & $41.4 \pm 0.3$ \\
\hline
\end{tabular}

+ Dry base, ${ }^{*}$ Wet base. 


\subsection{Density}

Density is an important parameter for plastic composites in view of weight reduction. The average value obtained in the case of apparent density of coffee hulls powder is

$$
\rho_{v}=0.940 \pm 0.002 \mathrm{~g} / \mathrm{cm}^{3}
$$

This density can be compared to the density of plant fibers such as oil palm fiber.

The average value obtained in the case of wet density is $\rho_{m}=0.789 \pm 0.003$ $\mathrm{g} / \mathrm{cm}^{3}$. This value compare to the density values of some plant fibers used to reinforced polymer such as kenaf fibers $\left(0.6-1.5 \mathrm{~g} / \mathrm{cm}^{3}\right)$, Oil palm fiber $(0.7-1.6$ $\left.\mathrm{g} / \mathrm{cm}^{3}\right)$ or sisal $\left(1.2 \mathrm{~g} / \mathrm{cm}^{3}\right)$ shows that composites obtain after processing will be light [22] [23] [24] [25].

\subsection{Thermal Analysis}

The ATG-DTG curves of the coffee hulls are shown in Figure 4. Thermogravimetric analysis (ATG) (in red) provides the loss of mass of the material during thermal degradation. The heat treatment phenomenon is described by [26]. The second derivative of thermogravimetric analysis (DTG) (in blue) gives the degradation temperatures of the hulls as defined by [26].

Observation of the curve shows that around $440^{\circ} \mathrm{C}$, the biomass has been completely consumed.

Figure 4 shows four main phases of mass loss. The first mass loss of $8.00 \%$ by weight is located between $40^{\circ} \mathrm{C}$ to $100^{\circ} \mathrm{C}$ and has a peak around $86^{\circ} \mathrm{C}$; it corresponds to the evaporation of the water present in the hulls. The second loss of mass correspond to mass loss of $64.50 \%$ is observed between $300^{\circ} \mathrm{C}$ and $400^{\circ} \mathrm{C}$, with a DTG maximum at $321^{\circ} \mathrm{C}$, It is assigned to the degradation of polysaccharides (hemicelluloses and cellulose) in the fiber of coffee hulls [27]. The third loss of $22,60 \%$ observed between $321^{\circ} \mathrm{C}$ and $401^{\circ} \mathrm{C}$ would be due to the degradation of cellulose; in fact cellulose would degrade around $401^{\circ} \mathrm{C}$. Between $401^{\circ} \mathrm{C}$ and $423^{\circ} \mathrm{C}$, a loss of $5.12 \%$ is observed having a peak around $423^{\circ} \mathrm{C}$, which would be due to the degradation of the lignin at $423^{\circ} \mathrm{C}$ [27].

We note that these results are in agreement with the chemical composition of coffee hulls: the major constituents of which are cellulose, hemicellulose and lignin; they degrade with a strong loss of mass [28].

In addition, hemicelluloses decompose at low temperatures because their molecular chains are short. In addition to their low molecular mass, they have less regular structures in their chains [28].

The curve of Figure 4 shows four thermal phenomena for coffee hulls. One endothermic peak observed at lower temperature around $86^{\circ} \mathrm{C}$ and three exothermic peaks range between $321^{\circ} \mathrm{C}, 401^{\circ} \mathrm{C}$ and $423^{\circ} \mathrm{C}$. The first thermal incident was attributed to evaporation of water molecules from fibers; the second third and fourth respectively represent the degradation of holocelluloses, celluloses and lignin from the coffee hulls [28] (Table 2). 


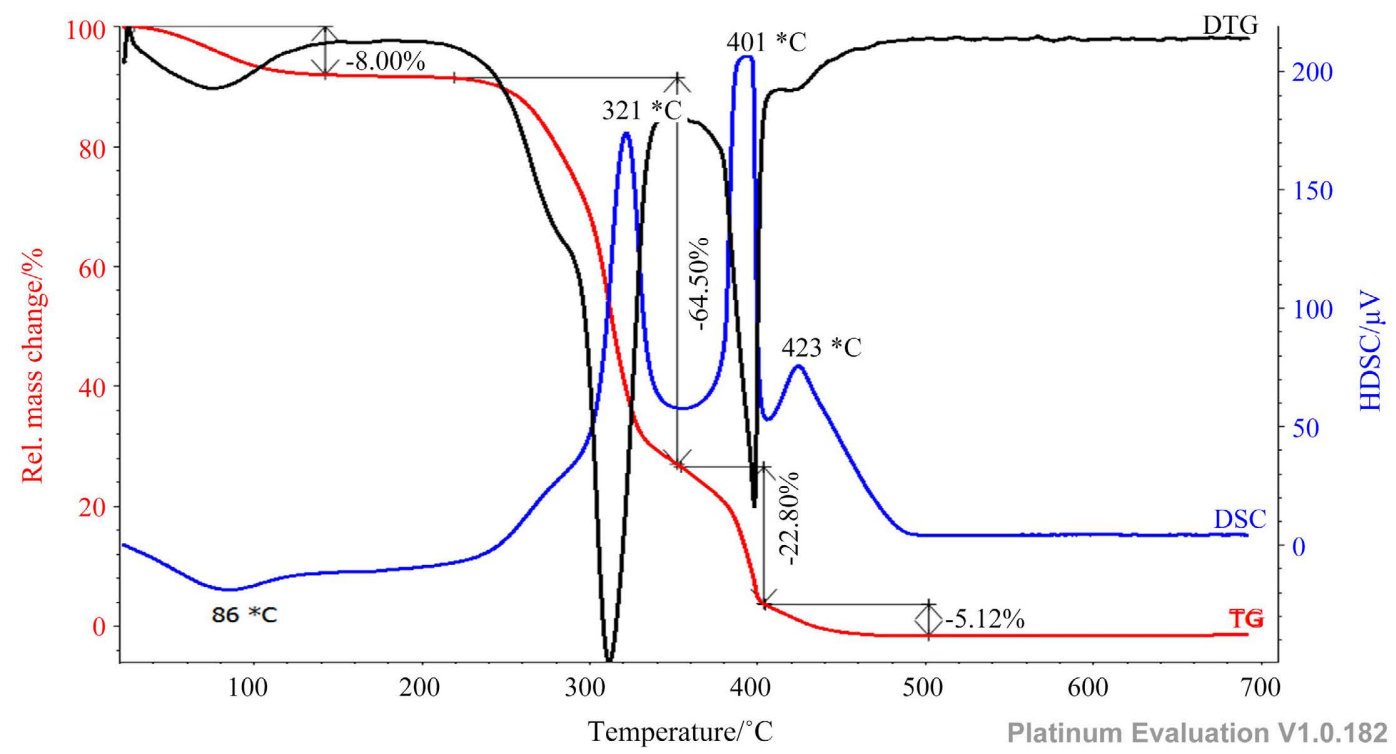

Figure 4. Thermogravimetric and differential scanning calorimetry of raw coffee hulls.

Table 2. Types of thermal phenomena.

\begin{tabular}{ccccc}
\hline & $\begin{array}{c}\text { Temperature } \\
\left({ }^{\circ} \mathrm{C}\right)\end{array}$ & $\begin{array}{c}\text { Partial loss } \\
\text { of mass (\%) }\end{array}$ & $\begin{array}{c}\text { Total loss } \\
\text { of mass (\%) }\end{array}$ & Type of reaction \\
\hline & 86 & 8 & & Endothermic \\
$\begin{array}{c}\text { Pulp of } \\
\text { coffee hulls }\end{array}$ & 321 & 64.50 & 100 & Exothermic \\
& 401 & 22.8 & & Exothermic \\
& 423 & 5.12 & & Exothermic \\
\hline
\end{tabular}

\subsection{Infrared Fourier Transform Analysis}

Figure 5, FT-IR analysis of coffee hulls shows different peak intensities

The large peak intensity at $3299 \mathrm{~cm}^{-1}$ can be attributed to O-H stretching group of alcohol (cellulose content in coffee pulp). The intensity $2926 \mathrm{~cm}^{-1} \mathrm{can}$ be attributed to $\mathrm{C}-\mathrm{H}$ stretching group of alkanes or the vibration of methoxy group of lignin. The intensity peak between $1300-1150 \mathrm{~cm}^{-1}$ and those of 1238 $1016 \mathrm{~cm}^{-1}$ could be attributed to $\mathrm{C}-\mathrm{O}$ stretch of alcohols, esters or ethers.

These results are in agreement with data found in the literature concerning coffee pulp. The study indicates that coffee skin can be an interesting filler for polymeric composites; its properties can be ameliorated by pretreatments techniques.

\subsection{Morphological Investigation (SEM)}

Figure 6(a) shows that the neat coffee hulls exhibits a rough surface due to the presence of non cellulosic materials, while figure (b) shows mercerized fibers that were made to react with caustic soda; In this image (b) gaps between the fibers can be clearly observed in, which indicate the partial removal of lignin and hemicellulose. Also, this can be related with mechanical properties enhancement 
that can be observed in the composites after addition of treated coffee pulp.

\subsection{Water Absorption and Mechanical Test}

\subsubsection{Mechanical Test}

This analysis allows us to measure the maximum stress at which the composite can resist the extreme conditions of solicitation. The values of the tensile module and its tensile strength are recorded in Table 3 . The observation of the table reflects that the resistance to the fraction decreases with the addition of the fiber of the coffee shell. This result can be explained by the poor adhesion between the fiber which is hygrophilous and the LLPDE which is hydrophobic. Similarly, according to Sahoo et al. [29] the incorporation of coffee shell fiber into the LLPDE gradually reduces the tensile strength of composites [30].

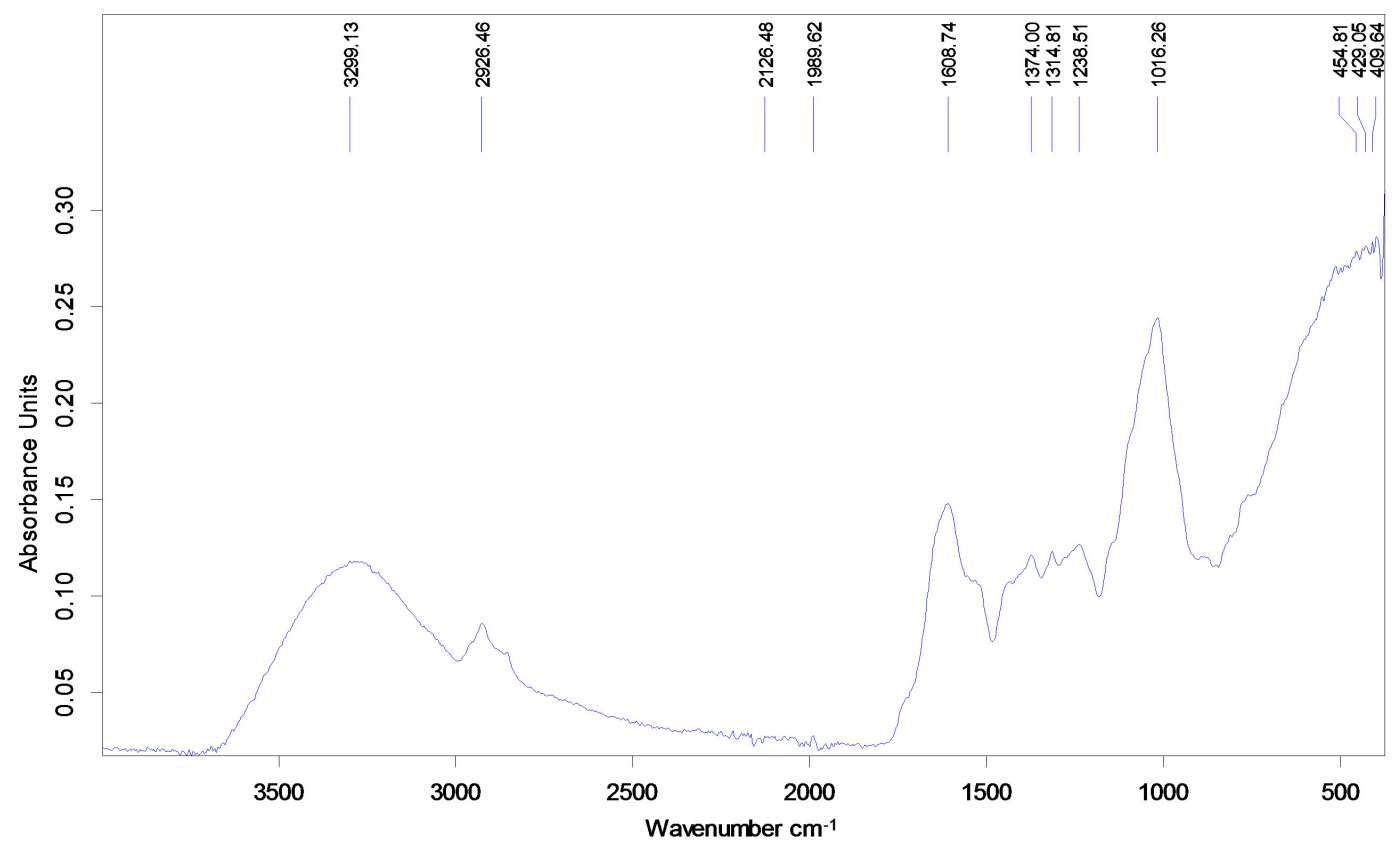

Figure 5. Infrared of raw Coffee shell pulp.



(a)

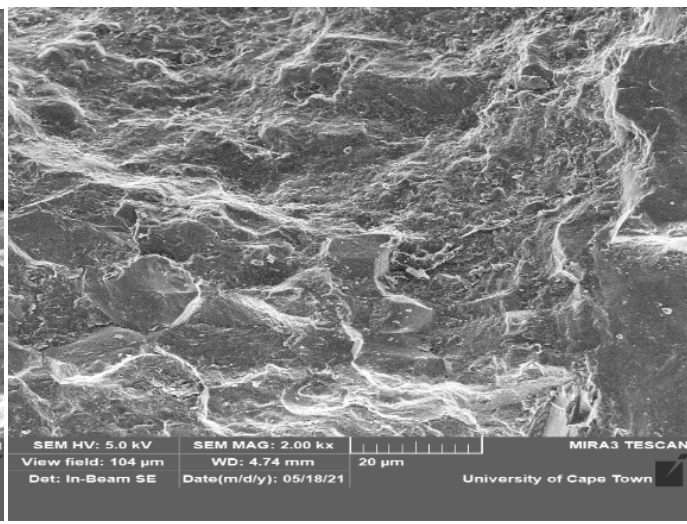

(b)

Figure 6. Scanning electron micrographs of coffee hulls (a) (untreated or, neat coffee skin); (b) (mercerized coffee skin). 
Table 3. The constituents of the manufactured composite materials with their tensile strength, elongation at break and water absorption.

\begin{tabular}{ccccc}
\hline \%LLDPE & $\begin{array}{c}\text { \% of } \\
\text { coffee hulls }\end{array}$ & $\begin{array}{c}\text { Tensile strength } \\
(\mathrm{MPa})\end{array}$ & $\begin{array}{c}\text { Elongation } \\
\text { at break (\%) }\end{array}$ & $\begin{array}{c}\text { Water absorption } \\
(\%)\end{array}$ \\
\hline 100 & 0 & $24.9 \pm 1.5$ & $3.4 \pm 0.1$ & $0.23 \pm 0.1$ \\
90 & 10 & $18.1 \pm 1.5$ & $3.28 \pm 0.08$ & $3.34 \pm 1.09$ \\
80 & 20 & $18.4 \pm 1.5$ & $3.2 \pm 0.1$ & $4.76 \pm 0.78$ \\
70 & 30 & $17.6 \pm 1.5$ & $3.1 \pm 0.1$ & $6.76 \pm 1.67$ \\
\hline
\end{tabular}

\subsubsection{Water Absorption Test}

Figures in Table 3 shows that an increase in the percentage of filler leads to an increase of water absorption. Study has shown that water absorption by bio composites occur at the level of fibers, matrix being generally thermoplastics. The higher the proportion of fibers, the more water is absorbed.

\section{Conclusion}

The properties of coffee hulls fiber-based LLDPE composites, in general, depend on coffee hulls fiber percentage, as well as the addition of coupling agent to ensure better interaction between coffee hulls fiber and matrix. The addition of coffee hulls fiber produces an environmentally friendly material without loss of the desired characteristics of the virgin LLDPE. It is clear that coffee hulls fiber has great potential as a filler and reinforcement for composites requiring similar properties to LLDPE.

\section{Acknowledgements}

The authors acknowledge to the Research Unit for Macromolecular Chemistry, Applied Inorganic Chemistry Laboratory, Faculty of Science, University of Yaounde I, Yaounde, Cameroon for the technical support.

\section{Conflicts of Interest}

The authors of this manuscript declare that they do not hold any conflicts of interest that might have any bearing on research reported in their submitted manuscript.

\section{References}

[1] Carbonell-Verdú, A., García-García, D., Jordá, A., Samper, M.D. and Balart, R. (2015) Development of Slate Fiber Reinforced High Density Polyethylene Composites for Injection Molding. Composites Part B: Engineering, 69, 460-466. https://doi.org/10.1016/j.compositesb.2014.10.026

[2] Dominici, F., García, D.G., Fombuena, V., et al. (2019) Bio-Polyethylene-Based Composites Reinforced with Alkali and Palmitoyl Chloride-Treated Coffee Silver Skin. Molecules, 24, 3113. https://doi.org/10.3390/molecules24173113

[3] Zhang, H. (2014) Effect of a Novel Coupling Agent, Alkyl Ketene Dimer, on the Mechanical Properties of Wood-Plastic Composites. Materials \& Design, 59, 130-134. 
https://doi.org/10.1016/j.matdes.2014.02.048

[4] Garcia-Garcia, D., Carbonell-Verdu, A., Jordá-Vilaplana, A., Balart, R. and Garcia-Sanoguera, D. (2016) Development and Characterization of Green Composites from Bio-Based Polyethylene and Peanut Shell. Journal of Applied Polymer Science, 133, Article ID: 43490. https://doi.org/10.1002/app.43940

[5] Das, O., Sarmah, A.K. and Bhattacharyya, D. (2015) A Sustainable and Resilient Approach through Biochar Addition in Wood Polymer Composites. Science of the Total Environment, 512, 326-336. https://doi.org/10.1016/j.scitotenv.2015.01.063

[6] Bayer, J., Granda, L.A., Méndez, J.A., Pèlach, M.A., Vilaseca, F. and Mutijé, P. (2017) Cellulose Polymer Composites (WPC). In: Deans, M., Ed., Advanced High Strength Natural Fibre Composites in Construction, Elsevier, Berkeley, 115-139. https://doi.org/10.1016/B978-0-08-100411-1.00005-4

[7] Spear, M., Eder, A. and Carus, M. (2015) Wood Polymer Composites. In: Ansell, M., Ed., Wood Composites, Elsevier, Berkeley, 195-249. https://doi.org/10.1016/B978-1-78242-454-3.00010-X

[8] Saba, N., Paridah, M. and Jawaid, M. (2015) Mechanical Properties of Kenaf Fibre Reinforced Polymer Composite: A Review. Construction and Building Materials, 76, 87-96. https://doi.org/10.1016/j.conbuildmat.2014.11.043

[9] Quiles-Carrillo, L., Montanes, N., Garcia-Garcia., D., Carbonell-Verdu, A., Balart, R. and Torres-Giner, S. (2018) Effect of Different Compatibilizers on Injection-Molded Green Composite Pieces Based on Polylactide Filled with Almond Shell Flour. Composites Part B: Engineering, 147, 76-85.

https://doi.org/10.1016/j.compositesb.2018.04.017

[10] Chan, C.M., Vandi, L.J., Pratt, S., Halley, P., Richardson, D., Werker, A. and Laycock, B. (2018) Mechanical Properties of Poly(3-hydroxybutyrate-co-3-hydroxyvalerate)/Wood Flour Composites: Effect of Interface Modifiers. Journal of Applied Polymer Science, 135, 46828. https://doi.org/10.1002/app.46828

[11] Echeverria, M.C. and Nuti, M. (2017) Valorization of the Residues of Coffee Agro-Industry: Perspectives and Limitations. The Open Waste Management Journal, 10, 13-22. https://doi.org/10.2174/1876400201710010013

[12] Hahladakis, J.N., Velis, C.A., Weber, R., Iacovidou, E. and Purnell, P. (2018) An Overview of Chemical Additives Present in Plastics: Migration, Release, Fate and Environmental Impact during Their Use, Disposal and Recycling. Journal of Hazardous Materials, 344, 179-199. https://doi.org/10.1016/j.jhazmat.2017.10.014

[13] Bachmann, N., Deront, M., Fruteau, H., Holliger, C., Membrez, Y. and Wellinger, A. (2011) Optimisation des tests standardisés de digestibilité dans des réacteurs batch. Office fédéral de l'énergie OFEN Programme de recherche énergétique, Berne, Laboratoire de Biotechnologie Environnemental (LBE), 1015 Lausanne.

[14] Wolff, J.P. (1968) Méthodes d'analyse des corps gras. Azoulay, Paris.

[15] Monties, B. (1984) Dosage de la lignine insoluble en milieu acide: Influence du préraitement par hydrolyse acide sur la lignine Klason de bois et de pailleAgronomie. EDP Sciences, 4, 387-392. https://doi.org/10.1051/agro:19840410

[16] Ernesto de la Torre, C. (2015) Préparation de charbon actif à partir de coques de noix de palmier à huile pour la récupération d'or et le traitement d'effluents cyanurés. Thèse, Université Catholique de Louvain, $350 \mathrm{p}$.

[17] Dias, O.A.T., Negrão, D.R., Silva, R.C., Funari, C.S., Cesarino, I. and Leao, A.L. (2016) Studies of Lignin as Reinforcement for Plastics Composites. Molecular Crystals and Liquid Crystals, 628, 72-78. https://doi.org/10.1080/15421406.2015.1137677 
[18] Nanfack, N.C. (2015) Production de biogas à partir des dechets de cacao. Mémoire de Master en Génie des Procédés et Ingénierie, (ENSAI), Université de Ngaoundéré, Cameroun, $96 \mathrm{p}$.

[19] Daud, Z., Kassi, A.S., Aripin, A.M., Awang, H. and Hatta, M.Z. (2013) Chemical Composition and Morphological of Cocoa Pod Husks and Cassava Peels for Pulp and Paper Production. Australian Journal of Basic and Applied Sciences, 7, 406-411.

[20] Vriesmann, L.C., Amboni, R.D. and Petkowicz, C.L. (2011) Cacao Pod Husks (Theobroma cacao L.): Composition and Hot-Water-Soluble Pectins. Industrial Crops and Products, 34, 1173-1181. https://doi.org/10.1016/j.indcrop.2011.04.004

[21] Bai, Y.Y., Xiao, L.P., Shi, Z.J. and Sun, R.C. (2013) Structural Variation of Bamboo Lignin before and after Ethanol Organosolv Pretreatment. International Journal of Molecular Sciences, 14, 21394-21413. https://doi.org/10.3390/ijms141121394

[22] Balakrishnan, P., John, M.J., Pothen, L., Sreekala, M.S. and Thomas, S. (2016) Natural Fibre and Polymer Matrix Composites and Their Applications in Aerospace Engineering. In: Advanced Composite Materials for Aerospace Engineering, Woodhead Publishing, Sawston, 365-383.

https://doi.org/10.1016/B978-0-08-100037-3.00012-2

[23] Verma, D. and Senal, I. (2007) Natural Fiber-Reinforced Polymer Composites. Biomass, Biopolymer-Based Materials, and Bioenergy, 44, 129.

[24] Kumar, R., Ul Haq, M.I., Raina, A. and Anand, A. (2019) Industrial Applications of Natural Fibre-Reinforced Polymer Composites-Challenges and Opportunities. International Journal of Sustainable Engineering, 12, 212-220. https://doi.org/10.1080/19397038.2018.1538267

[25] Menezes, P.L., Rohatgi, P.K. and Lovell, M.R. (2012) Studies on the Tribological Behavior of Natural Fiber Reinforced Polymer Composite. In: Green Tribology, Springer, Berlin, 329-345. https://doi.org/10.1007/978-3-642-23681-5 12

[26] Manimaran, P., Kumar, C., Bharanirajan, R. and Premnauth, I. (2016) Investigations on Mechanical Properties of Al 8011 Reinforced with Micro B4C/Red Mud by Stir Casting Method. Journal of Electronic Design and Technology, 7, 32-38.

[27] Djomi, R., Meva'a, L.J.R., Nganhou, J., Mbobda, G., Njom, A.E., Bampel, Y.D.M. and Tchinda, J.-B.S. (2018) Physicochemical and Thermal Characterization of Dura Palm Kernel Powder as a Load for Polymers: Case of Polyvinyl Chloride. Journal of Materials Science and Chemical Engineering, 6, 1-18. https://doi.org/10.4236/msce.2018.66001

[28] Samomssa, I., Nono, Y.J., Tsamo, C., Dinica, M.R. and Kamga, R. (2019) Influence of Physico-Chemical Parameters on Fuel Briquettes Properties Formulated with Mixture of Biomasses. Journal of Environmental Science and Pollution Research, 5, 338-341. https://doi.org/10.30799/jespr.165.19050202

[29] Sahoo, S., Misra, M. and Mohanty, A.K. (2011) Enhanced Properties of Lignin-Based Biodegradable Polymer Composites Using Injection Moulding Process. Composites Part A: Applied Science and Manufacturing, 42, 1710-1718. https://doi.org/10.1016/j.compositesa.2011.07.025

[30] Sánchez, C.G. and Alvarez, L.A.E. (1999) Micromechanics of Lignin/Polypropylene Composites Suitable for Industrial Applications. Die Angewandte makromolekulare Chemie, 272, 65-70.

https://doi.org/10.1002/(SICI)1522-9505(19991201)272:1<65::AID-APMC65>3.0.C $\underline{\mathrm{O} ; 2-5}$ 